\title{
The Knights in the Middle Ages of England
}

\author{
Ruijuan Yin \\ Faculty of Literature, Guangxi Normal University \\ Guilin 541004, China
}

Tel: 86-29-3375-3279 E-mail: zoeyinruijuan@qq.com

\begin{abstract}
Chivalry was a special phenomenon in the Middle Ages of Europe, and was also a part of the military system in the Middle Ages of Europe. Equites first came into military and civil posts signed by Augustus, and then the number of such posts multiplied in the course of time, and finally in the third century the Equites replaced senators in holding the highest responsibility. The chivalry of England made its infancy in the Anglo-Saxon period because of the rise of a series of wars. In the feudal relations, wars became the most important prerequisite for the existence of the relationship between knights and kings. If the feudal monarchies or feudal lords did not need knights for fighting, then the existence would lose its base. Knights' spirit was composed of moral qualities, such as bravery, loyalty, generosity, and honor as its core, all of which should be complied with a knight. The knights' spirit was virtually an aspect of the chivalry. The decline of chivalry had the extremely complex reasons, including military, economics, and religion and so on. Subsequently the rising urban aristocracy relied on the early capitalism economy and was superior to the feudal one. The decline of chivalry had a great influence upon modern Britain's development, which included social structure, economic basis and political system. After the decline of chivalry, the former stratum of knighthood began to polarize. Gentry and the middle level emerged and then the social structure changed from two-tiered structure to three-tiered structure. Chivalry's decline led to the commercialization of British agriculture and the trend of capitalism. With the vanishing of chivalry, nobility's power was reduced and the Crown was enriched, and balance shifted
\end{abstract}

Keywords: Knight, Chivalry, Feudalism

Knights and the chivalry accelerated the process of social civilization in the Middle Ages of England. The Equites was in the lowest level in the aristocracy. The chivalry influenced military, education and culture in Britain. And the chivalry was an important part of English feudalism.

\section{The establishment of chivalry}

Individualism is fundamental characteristic of the English people. Since King Arthur, it had the Knights of the Round fighting for freedom and equality. From the beginning of the middle of 5th century, the Anglo-Saxon began to invade England. The conquest to England speeded up the formation of the England feudal system. During the two hundred years of fighting in the war, a series of feudal kingdoms were set up. Sovereign princes gave their land to the military aristocracy by instrument. Then the military aristocracy changed their identification into land aristocracy that was very like the landholder. The land aristocracy sublet their land to farmers and collected rents, and made preparations for the cost of living and their weapons and equipments from the land entirely. As a result, sovereign princes and the land aristocracy made a close relationship, and the feudal land tenure and the obligation got closed too. These aristocracies were knights at the early time. This is the origin of the England chivalry.

The Angles and Saxons soon became the most powerful tribes in England. A lot of wars were happened between them. By the 8th century, there were only seven kingdoms. They are called the Heptarchy. After the late 8th century, Denmark began attacking England and robbing the people. By the end of the 9th century, England was invaded by Danish Vikings. In the 9th century, the invasion scale increased, the fight against Danish invasion in England was becoming the main task and mission. England's military system was made by the land aristocracy' forces and soon exposed their weaknesses at the beginning of the war. In 886, Alfred defeated the Danes and divided the country, giving them the northeastern part of England. The armed forces of England were composed of the land aristocracy. The soldiers' weapons and equipments were provided by their lords. 
Alfred died in 899 . During the early 10th century, Alfred's successors again conquered the Danelaw. But in the late 10th century, under the weak king Ethelred II, fresh waves of Danish fighters attacked again. Instead of fighting them, Ethelred II collected taxes and paid them to go away, but each year the Danish demanded more. So the poor could not bear the burden of heavy taxes and even the rich suffered. Before the invasion of Denmark, members of the communes had better economic conditions, adequate sources of troops were adequate, but anti-invasion war has seriously damaged England's economy, and a war indemnity reduced their wealth, these two greatly weakened the England army's combat effectiveness. During Alfred the Great's reigning period, the army carried out two reforms in order to enhance the combat effectiveness of the armed forces. The first was to depart the army into two parts, one served home, and the other went to the war. The second was the establishment of a regular troop. The land aristocracy at this time was different from the past because they had money. And they were professional military officers and were awarded the land and hereditary. This is the beginning of chivalry, and the formation of the Equites.

After Hastings the confiscation of Saxon estates began, and it went on gradually all over the country until the upper class of Saxon landholders were displaced by the Norman barons. There formed a hard and ruthless military caste as a new governing class, with their own ideas of law, stone castles went up everywhere. Knights were a part of the new governing class in fact.

When England made feudal system evolution slowly, Duke of Normandy had developed the feudal system rapidly across the sea. Normandy had been established a fairly complete system of knights before William became the Prince. As soon as William had been crowned, he began to establish a strong central government in England and adopt some systems which had been so successful in Normand. This was called the feudal system, and it was based on the ownership of land. The life of all classes was controlled by strict rules. William took the land away from its English owners and divided it among a number of great Norman lords and the lords' land was further divided among the 5,000 knights who had fought at Hastings. The Equites was the lowest class of the aristocracy. Knights were small landholders who were also experienced professional soldiers. And all the lords and knights should swear loyalty to the kings. The nation as the basis of economic organization was recognized.

Shortly before William's death in 1087, he sent out men to make a detailed record of all the wealth of England. The record, as the Domesday Book, was a rich source of information about England in Middle Age. It recorded how much land and other property there were in England, who held it, and what taxes and services the landholders owed the kings for their property.

Feudalism was indeed characteristic of social and governmental structure in all aspects, including military, economic, political and judicial. It made for stability in social, and was the foundation of the stability of Middle Age. When the feudalism established, the chivalry established too. The danger of feudalism was the excessive power of local territorial magnates with their powers of private rights. In England there were the shire counts and these hundreds of courts were under royal control, knights were controlled by their lords in courts but swear to the kings. Kings were careful to keep control of the sheriffs in the counties as royal officers and to keep the post did not hereditary.

\section{The development of chivalry}

Two events contributed the formation of chivalry in France in 8th century. One was the war between England and Normans in 1066, by which feudalism was brought into England. The Equites was blown up and the chivalry had its soil. The other was the marriage of Eleanor and Henry. Many behavior regulations and ideology in the battle from France were also introduced into England. And a great many troubadours brought the idea of love into the count of England. Love became an important part of the knight spirit. The kings and the aristocracy including the Equites had a mutual constraint relationship. To the aristocracy, they pledged loyalty to the kings not only because their religions but also for their political position which was based on economic benefits. But the knights had another spirit of their own thoughts as the knight spirit. They pledged allegiance and loyalty to the king, but not the lords as their obligation and highest honor.

Since the establishment of the knight estate, the chivalry including knights' behavior and etiquette regulations were developed a lot by knights' life style and knights' culture. The life style of knights changed from the 16th century. The place where knights had received education changed from court to school. University education took place of traditional family education. Knights didn't have to be knighted anymore. Tournament was not a preparation for battle but some kind of performances. Knights' behaviors that had the trend of civilization were regulated by the church and courtly culture. The church made rules to regulate the brutal character of knights and managed to make them be the loyal warriors of the God. The organizations such as the Teutonic Order and the Hospital Brotherhood set a successful example for moralizing knights. Influenced by the War, the tournament, the court and the church, knights became brave, modest, polite and pious. Those spirits of knights were written down into the literature, which later influenced reality. From Beowulf to Legend of Arthur, we would notice that connotations of chivalry were increasingly rich. Heraldry system deriving from the tournament constituted another important and essential factor of knights' culture. Heraldry was the symbol of knights and aristocracies' status. 
In other countries the feudatories and the communes were so powerful that they fought for their own independence. But this was not what happened in England, because the state founded by Norman kings was too strong. The struggle of classes for power had to take place within this framework. Since Parliament became the starting-point of England's modern and law, it sought another way to limit the Crown and the great feudal baronies.

As far as the relationship between lords and tenants was concerned, William I took two measures to control the tenants. One was to compile Domesday Book; the other was to ask his tenants to swear in Salisbury. The first character of English chivalry was that English knights were controlled directly by the kings. Owing to all these reasons mentioned above, the king of England carried out the Shield Money prior to other kings. The second character of English chivalry was that knights gradually handed in some shield money instead of implementing their obligation of fighting in the batter for their lords.

Under great pressure of a group barons and church leaders, John approved the articles on June 15th, 1215. These articles were written out in legal form as Magna Carta. It had 63 articles, which made the kings promise to give many rights to the nobles including the Equites, but ordinary people and peasants were hardly mentioned in the charter, even though they were the largest part of England's population.

From the early days, the Crown in England was restrained by the church and the aristocracy organizations, which reduced the hegemony of kings. By making this tradition continued, British had seldom tyrant and tyranny.

From the 13th to the 15th century, the knight estate was divided into two parts according to their wealth and station. This change happened inside for economic reasons. Some of the knights started to operate their lands in capitalistic way. Some merchants, bankers and lawyers, who also invested lands in the same way, shared the same interests with knights. They formed a new gentry's estate. This estate was a flowing and open estate. In addition to original group of people, it enrolled large number of industry capitalists. Spirits of knights mixed with capitalistic spirits among this estate, then the gentry's demeanor came into being. The third character of English chivalry was that spirits of knights transformed into gentry demeanor. The chivalry got the feudal and capitalism economic factors at the same time, and the knights made a dual role in this transition stage.

\section{The decline of the chivalry}

In the late Middle Age, change of weapons had finally caused knights disastrous defeat for knights in battlefield. The real force of strong, England was exerted against France. It led to the Hundred Years' War. The chivalry was a kind of military system, and its decline mainly was as a result of defeated militarily. The chivalry was a constituent of feudal system and a performance of the feudalism in militarily. Therefore change of economical domain in England had the huge influence on the military system. The decline of chivalry had the extremely complex reasons, including the military, the economy, the religion and so on. Subsequently the rising urban aristocracy who relied on the early capitalism economy had much more superiority to the feudal one. The shield money implementation urged the knight to transform to the professional soldier. Finally the knight system was vanished and the knight happened to be an empty honor.

In 1159, Henry II adopted a series designed to shake off dependence on the knights of the measures such as the recruitment of mercenaries for the war. The knights could also use money on behalf of the service and so on. These reforms showed that knight system began moved and the foundation of the Equites was weakened. Knight's system was also on the inevitable decline. In 1504, Henry VII enacted "legislation to ban soldiers home". The regulations gave legal recognition to the king who can only have the army, and the kings became the only commander in chief of the armed forces. And this showed that the chivalry system was fully declined.

\section{Conclusion}

After the Norman's conquest, the chivalry in England was based on the establishment of a powerful monarchy, which made England the political path of development comparing with Europe's fragmented political structure. Chivalry is a product of the feudal society. As a system of military, chivalry was vanished. But the Equites as a level of class and aristocratic systems were preserved. Knight became a symbol of status and honor. In May 1661, British had the opening of the parliament which was the longest one in the history was known as the parliament of knights with its members most were royalist believing in state religion. This shows that the chivalry makes influence on the British political system, and in contrast, the chivalry takes a dual role in feudal and capitalism economic of British society and seems to have more far-reaching impact.

\section{References}

A. L. Rowse. (1943). The Spirit of English History. London: J. Cape.

Qian, Chengdan \& Chen, Xiaolu. (1991). Between the Tradition and Transition: Study on the British Culture and the American Culture. Zhejiang: Zhejiang People's Publishing House. 